\title{
Budi Iman Santoso Assessment (BISA): a model for predicting levator ani injury after vaginal delivery
}

Budi I. Santoso

Department of Obstetrics and Gynecology, Faculty of Medicine, Universitas Indonesia, Jakarta, Indonesia

\begin{abstract}
Abstrak
Latar belakang: Belum ada usaha maupun penelitian yang mampu memadukan berbagai faktor risiko untuk memprediksi terjadinya kerusakan otot levator ani akibat persalinan pervaginam. Penelitian ini bertujuan untuk mengetahui indeks yang dapat digunakan untuk memprediksikan kerusakan levator ani pada persalinan pervaginam.

Metode: Penelitian kohort prospektif di dua rumah sakit di Jakarta tahun 2010-2011. Kriteria subjek adalah wanita hamil nulipara tanpa kerusakan levator ani saat hamil dan melahirkan pervaginam. Kerusakan levator ani diukur dengan USG 4 dimensi saat hamil dan tiga bulan pasca melahirkan. Variabel yang diteliti adalah usia, indeks masa tubuh, cara persalinan pervaginam, berat badan bayi lahir, episiotomi, robekan perineum, dan lamanya kala 2. Model prediksi dianalisis dengan analisis regresi logistik.
\end{abstract}

Hasil: Sebanyak 182 subjek direkrut dengan 124 subjek memenuhi kriteria dan 104 subjek dapat dianalisis. Insiden kerusakan levator ani pada tiga bulan adalah sebesar 15,4\% (IK 95\%: 8,6-23\%). Diperoleh dua model prediksi. Model prediksi pertama terdiri dari berat bayi $(O R=5,36$ IK 95\%: 1,08-26,59), episiotomi $(O R=5,41$ IK 95\%: 0,94-31,18), dan lama kala dua $(O R=15,27$ IK 95\%: 3,15-73,96). Model prediksi kedua terdiri dari lama kala dua $(O R=9,51$ IK 95\%: 1,23$68,10)$ dan robekan perineum (OR=142,70 IK 95\%: 14,13-1440,78).

Kesimpulan: Variabel yang dapat memprediksikan kerusakan levator ani adalah berat bayi, episiotomi, dan kala dua pada model 1 dan lama kala dua serta robekan perineum pada model 2. (Med J Indones. 2012;21:102-7)

\begin{abstract}
Background: There have been no attempts or studies to integrate various risk factors that can be utilized to predict levator ani injury caused by vaginal delivery. This study was aimed to establish an index measurement system by using various risk factors for predicting levator ani injury in vaginal delivery.

Methods: A prospective cohort was conducted at two hospitals in Jakarta between 2010 and 2011. The subjects were nulipara pregnant women without levator ani injury during pregnancy and vaginal birth. Levator ani injury was evaluated using 4D USG during pregnancy and three months after delivery. The variables studied were age, body mass index, mode of delivery, fetal birth weight, episiotomy, perineum rupture and duration of second stage labor. Prediction model was analyzed using logistic regression analysis.

Results: There were 182 recruited subjects of which 124 subjects were eligible and only 104 subjects could be analyzed. Incidence of levator ani injury at three months after delivery was $15.4 \%$ (95\% CI: 8.6-23\%). Two prediction models were obtained. The first consisted of fetal birth weight ( $\mathrm{OR}=5.36,95 \%$ CI: $1.08-26.59)$, episiotomy (OR=5.41, 95\% CI: 0.94 $31.18)$, and duration of second stage labor $(\mathrm{OR}=15.27,95 \% \mathrm{CI}: 3.15-73.96)$. The second model consisted of duration of second stage labor $(\mathrm{OR}=9.51,95 \% \mathrm{CI}$ : $1.23-68.10)$ and perineum rupture $(\mathrm{OR}=142.70,95 \% \mathrm{CI}: 14.13-1440.78)$.

Conclusion: Fetal birth weight, episiotomy and duration of second stage labor could predict levator ani injury for model 1; while the variables of prediction for model 2 were duration of second stage labor and perineum rupture. (Med $\boldsymbol{J}$ Indones. 2012;21:102-7)
\end{abstract}

Keywords: Levator ani, prediction model

Levator ani muscle is one of important components of pelvic floor structure. Levator ani damage may result in impaired pelvic floor function, known as pelvic floor dysfunction. It includes various symptoms that could reduce quality of life such as urinary incontinence, fecal incontinence, pelvic organ prolapse and sexual dysfunction. ${ }^{1,2}$ Obstetricians and gynecologists have assumed that the natural mode of delivery or vaginal childbirth may contribute to pelvic floor dysfunction; particularly the levator ani damage. ${ }^{3}$ Prevalence of levator ani damage at 3-months after delivery as has been revealed by Dietz $^{4}$ is $15-30 \%$ in women with vaginal delivery.
However, until now, the clinical relevance of the association between levator ani damage and developing symptoms of pelvic floor dysfunction is still vague. Dietz ${ }^{4}$ even demonstrated that there were many women with levator ani damage who did not have symptoms of pelvic floor dysfunction. Moreover, the concern on pelvic floor dysfunction which leads to the selection Caesarean birth seems to be over-worried, since the Caesarian birth actually could only prevent 1 of 7 women from experiencing levator ani damage due to vaginal birth. ${ }^{5}$ It should be noted that the mortality risk of Caesarean birth increases up to five times compared to vaginal birth. Moreover, there are various risk factors 
for levator ani injury, i.e. demographic and obstetric risk factors. ${ }^{5}$ Demographic risk factors include maternal age, race, parity and body mass index (BMI). ${ }^{1,6,7}$ Obstetric risk factors include age at first delivery, mode of delivery, second stage period, fetal birth weight, episiotomy, and perineum rupture. ${ }^{3,4,6}$

Until now, there have been no attempts to integrate various risk factors that can be utilized to predict levator ani injury caused by vaginal delivery. Therefore, a scoring system that could predict the occurrence of levator ani injury is required. When the scoring system suggests a low risk of levator ani injury, then the patient could be convinced to choose vaginal birth without any fear of the developing pelvic floor dysfunction. Therefore, the aim of the present study was to establish an index measurement system by using various risk factors in predicting levator ani injury in vaginal delivery, which were represented in a comprehensive and integrated dynamic system model.

\section{METHODS}

The study was a prospective observational cohort study using a quantitative approach, which was followed by dynamic system assessment. This study was approved by The Ethical Committee of Faculty of Medicine, Universitas Indonesia, ref:200/PT02.FK/Etik/2010. There were three steps of assessment, i.e. the descriptive analysis, development of dynamic system model, and model simulation. Samples were collected using consecutive sampling at Cipto Mangunkusumo Hospital and YPK (Yayasan Pemeliharaan Kesehatan) Hospital between June 2010 and December 2011. Subjects were nulipara women who had their vaginal birth at maternal age of 37 weeks or more. The inclusion criteria were nulipara women who had planned to have vaginal birth with maternal age of 37 weeks or more, in healthy condition and could have normal delivery. The exclusion criteria were subjects with complications of pregnancy such as antepartum bleeding, was not able to deliver the baby at Cipto Mangunkusumo Hospital or YPK Hospital, subjects with pregnancy and comorbidities, such as preeclampsia, eclampsia, placenta previa and solution placenta, and subjects who already had levator ani avulsion prior to the delivery.

Data collection was performed through two steps, i.e. recruitment of subjects and examinations for evaluating levator ani injury. Nulipara women at maternal age of 37 weeks or more who were candidates for study subject will be drawn from pregnant women who had their routine medical visit at the Cipto Mangunkusumo Hospital or YPK Hospital and who had completed their examination according to the available protocol. The eligible subjects got explanation about the study conducted, and on their approval, they were asked to sign the informed consent form. BMI during pregnancy was calculated before pregnancy and classified according to maternal weight gain at near delivery. BMI classification was applied from table by Arisman. ${ }^{8}$ Antenatal examination, abdominal and pelvic floor ultrasound were performed as the initial examination to detect levator ani injury. Afterwards, when the subjects had their delivery, various parameter of levator ani risk factors were recorded (such as fetal birth weight, the duration of second stage labor, episiotomy). Moreover, the subjects were asked to have another visit for ultrasound examination at 6 weeks and 3 months later to establish the diagnosis of levator ani injury. All examinations were performed in blind method, i.e. the investigator did not aware about the obstetric data of the subjects. Data was processed using SPSS software version 11.0 and two steps were conducted, that were making description and explanation about the observed process, including the calculation and analysis of risk factors, which would be utilized for the model development.

\section{RESULTS}

Between June 2010 and December 2011, there were 182 subjects who wanted to participate in the study. About 53 subjects were excluded due to abdominal delivery (29.1\%), twenty subjects left the study at the 6 -weeks avulsion examination (11.0\%), and 5 subjects were excluded due to obvious levator ani avulsion on the antenatal examination (2.7\%). Characteristics of subjects based on demographic factors are given in table 1 and characteristics of subjects based on obstetric factors could be seen in table 2 .

Of 182 patients enrolled in the study, there were only 104 patients who were eligible for the analysis. There was no significant difference in age and BMI during

Table 1. Subject characteristics based on demographic factors

\begin{tabular}{lccc}
\hline Variables & Category & $\mathrm{n}$ & $\%$ \\
\hline Age (years) & $20-23$ & 25 & 24.03 \\
& $24-27$ & 41 & 39.42 \\
& $28-31$ & 28 & 26.92 \\
& $32-35$ & 8 & 7.69 \\
Education level & $36-$ max & 2 & 1.92 \\
& High school - University & 79 & 76.0 \\
BMI during pregnancy & Elementary - Junior High & 25 & 24.0 \\
& Low & 48 & 46.2 \\
& Normal & 41 & 39.4 \\
& High & 11 & 10.6 \\
& Obesity & 4 & 3.8 \\
\hline
\end{tabular}


Table 2. Subject characteristics based on obstetric factors

\begin{tabular}{llcc}
\hline \multicolumn{1}{c}{ Variables } & Category & $\mathrm{n}$ & $\%$ \\
\hline Mode of delivery & Vacuum & 17 & 16.3 \\
& Spontaneous & 87 & 83.7 \\
Perineum tear & Grade IV & 1 & 1.0 \\
& Grade III & 18 & 17.3 \\
& Grade II & 81 & 77.9 \\
& Grade I & 4 & 3.8 \\
Episiotomy & Yes & 40 & 38.5 \\
Duration of second stage labor & No & 64 & 61.5 \\
& $\geq 65$ minutes & 26 & 25.0 \\
Fetal birth weight & $<65$ minutes & 78 & 75.0 \\
& $\geq 3325 \mathrm{~g}$ & 23 & 22.1 \\
& $<3325 \mathrm{~g}$ & 81 & 77.9 \\
\hline
\end{tabular}

pregnancy between data that could be analyzed (104 cases) with could not be analyzed due to loss to follow up (20 cases) and the statistic results showing similar subject characteristics among the patients, i.e. age $(\mathrm{p}=$ $0.448)$, education $(\mathrm{p}=0.687)$ and pregnancy BMI $(\mathrm{p}=$ $0.791)$. Most subjects $(n=41,39.42 \%)$ were at $24-27$ years of age and the education level was high school to university in $79(76 \%)$ subjects. Most subjects had BMI as low, found in 48 subjects $(46.2 \%)$. Incidence of avulsion at 6 weeks and 3 months were $11.5 \%$ (95\% CI: 5.7-18.5\%) and 15.4\% (95\% CI: 8.6-23.0\%) respectively. There was one subject who demonstrated avulsion at the six weeks had but become normal at the three months period. Moreover, there were four subjects who had no avulsion at the six weeks but had avulsion at three months.

On bivariate analysis, perineum rupture $(\mathrm{p}<0.001)$, episiotomy $(\mathrm{p}<0.001)$, duration of second stage labor $(\mathrm{p}<0.001)$, and fetal birth weight $(\mathrm{p}=0.003)$ demonstrated significant association with avulsion at three months period after delivery. Meanwhile, BMI $(p=0.144)$ and mode of delivery $(p=0.208)$ were not associated with avulsion at three months period after delivery.

The numerical variables including the fetal birth weight and long duration of second stage periods appeared to have significant correlation with levator ani injury or avulsion at the third month. By using receiver operating characteristic (ROC) curve, an optimal cut-off point was found of $\geq 3325 \mathrm{~g}$ for the fetal birth weight and $\geq 65$ minutes for the duration of second stage labor.

Independent variables that fulfilled the criteria for multivariate analysis were BMI, mode of delivery, perineum rupture, episiotomy, duration of second stage labor and fetal birth weight. There were autocorrelation between perineum rupture and episiotomy. Therefore, this study developed two models, i.e. the first model without including perineum rupture (model 1) and the second model without including episiotomy (model 2). On multivariate analysis, stepwise logistic regression was performed with independent variables of BMI, mode of delivery, duration of second stage labor and fetal birth weight. On the third step, the variable of episiotomy was found statistically not significant ( $p=0.059)$; however, it was clinically significant since the odds ratio of episiotomy $(\mathrm{OR}=5.41)$ was greater than the minimal odds ratio, which was considered as significant $(\mathrm{OR}=3.0)$. Other variables (duration of second stage labor and fetal birth weight) were significant both statistically and clinically. The third step was decided as the final model for the first model (model 1), which was further transformed into a score system.

From the logistic regression analysis in model 1 , the result showed that

$\mathrm{Y}($ avulsion at the third month $)=-4.64+(1.69) *$ episiotomy $+(2.73) *$ second stage labor $+(1.68) *$ fetal birth weight

According to the model, the log of the odds of pregnant woman got avulsion at the third month was positively related with episiotomy, second stage labor and fetal birth weight (Table 3).

Afterward, the probability based on fetal birth weight, episiotomy and second stage labor were classified into 3 categories, i.e. low, moderate and high probabilities. The probability was considered low when it reached 0.96 percentages, 4.92 percentages, 4.96 percentages, 12.85 percentages and 21.87 percentages. It was considered moderate at 44.15 percentages and 44.37 percentages and the probability was considered high at 81.05 percentages (Table 4 ).

Table 3. Logistic regression analysis for model 1

\begin{tabular}{ccccccc}
\hline Predictor & $\beta$ & SE $\beta$ & Wald & df & p & OR \\
\hline Constant & -4.64 & 0.9 & 26.66 & 1 & $<0.001$ & 0.01 \\
Episiotomy & 1.69 & 0.89 & 3.57 & 1 & 0.059 & 5.41 \\
Second stage labor & 2.73 & 0.81 & 11.46 & 1 & 0.001 & 15.27 \\
Fetal weight & 1.68 & 0.82 & 4.22 & 1 & 0.040 & 5.36 \\
\hline
\end{tabular}

Hosmer \& Lemeshow $\mathrm{p}=0.32$ 
Table 4. Probability of avulsion based on logistic regression equation in model 1

\begin{tabular}{cccccccc}
\hline \multirow{2}{*}{ Variable } & Fetal weight $\geq 3325 \mathrm{~g}$ & \multicolumn{2}{c}{ Episiotomy } & \multicolumn{2}{c}{$\begin{array}{c}2^{\text {nd }} \text { stage } \geq \\
\text { minutes }\end{array}$} & $\begin{array}{c}\text { Probability } \\
(\%)\end{array}$ \\
\cline { 2 - 6 } Case 1 & Yes & No & Yes & No & Yes & No & 0.96 \\
Case 2 & $\checkmark$ & $\checkmark$ & & $\checkmark$ & & $\checkmark$ & 4.92 \\
Case 3 & & & & $\checkmark$ & & $\checkmark$ & 4.96 \\
Case 4 & & $\checkmark$ & $\checkmark$ & & & $\checkmark$ & 12.85 \\
Case 5 & $\checkmark$ & $\checkmark$ & & $\checkmark$ & $\checkmark$ & & 21.87 \\
Case 6 & $\checkmark$ & & $\checkmark$ & & & & 44.15 \\
Case 7 & & & & $\checkmark$ & $\checkmark$ & & 44.37 \\
Case 8 & $\checkmark$ & $\checkmark$ & $\checkmark$ & & $\checkmark$ & & 81.05 \\
\hline
\end{tabular}

Table 5. Logistic regression analysis for model 2

\begin{tabular}{lcccccc}
\hline \multicolumn{1}{c}{ Predictor } & $\beta$ & SE $\beta$ & Wald & df & p & OR \\
\hline Constant & -5.22 & 1.19 & 19.29 & 1 & $<0.001$ & 0.01 \\
Second stage labor & 2.21 & 1.02 & 4.67 & 1 & 0.031 & 9.51 \\
Perineum rupture & 4.96 & 1.18 & 17.68 & 1 & $<0.001$ & 142.70
\end{tabular}

Hosmer \& Lemeshow $\mathrm{p}=0.653$

Table 6. Probability of avulsion based on logistic regression equation on model 2

\begin{tabular}{cccccc}
\hline \multirow{2}{*}{ Variable } & \multicolumn{2}{c}{$2^{\text {nd }}$ stage $\geq 65$ minutes } & \multicolumn{2}{c}{ Perineum Rupture } & \multicolumn{2}{c}{$\begin{array}{c}\text { Probability } \\
(\%)\end{array}$} \\
\cline { 2 - 5 } & Yes & No & Yes & No & 0.54 \\
Case 1 & & $\checkmark$ & & $\checkmark$ & 4.72 \\
Case 2 & $\checkmark$ & & & $\checkmark$ & 43.56 \\
Case 3 & & $\checkmark$ & $\checkmark$ & 87.60 \\
Case 4 & $\checkmark$ & & $\checkmark$ & & \\
\hline
\end{tabular}

In the second model without including episiotomy (model 2), the stepwise multivariate analysis of regression logistic was presented with independent variables of BMI, mode of delivery, perineum rupture, second stage labor and fetal birth weight. Based on clinical consideration, which is in keeping with the research proposal, i.e. the minimal odds ratio considered as significant was three; therefore, the fourth step was considered as the final model. The result for model 2 showed that

$\mathrm{Y}$ (avulsion at the third month $)=-5.22+(2.21)^{*}$ second stage labor

$$
+(4.96) * \text { perineum rupture }
$$

From model 2, we found that if woman had longer second stage labor and perineum rupture, the more likely it is that a woman got avulsion at the third month (Table 5).

Subsequently, the probability based on second stage labor and perineum rupture was classified into 3 categories, i.e. low, moderate and high probabilities. The probability was low when it reached the probability of 0.54 percentages and 4.72 percentages. Moderate probability was considered when the probability was 43.56 percentages and it was high probability when the probability was 87.60 percentages (Table 6).

\section{DISCUSSION}

The study demonstrated that of 182 subjects who were willing to participate in the study, only 104 (57.12\%) subjects were eligible for the analysis. The reasons were having abdominal delivery in 53 subjects $(29.1 \%)$, left the study in twenty subjects (11.0\%) and detected levator ani avulsion during antenatal examination in 5 subjects $(2.7 \%)$. Similar results were also found by Chan et $\mathrm{a}^{9}$ who studied about the prevalence of levator ani injury in primipara women in China. Of 339 subjects, there were only $201(59.3 \%)$ subjects who could be analyzed, about 
$62(18.3 \%)$ subjects had assisted surgical vaginal delivery by vacuum and forceps, fourteen $(4.1 \%)$ subjects had elective abdominal delivery and $62(18.3 \%)$ subjects had emergency abdominal delivery.

The subject characteristics revealed that the major age range was at 24-27 years, which was found in 41 $(39.42 \%)$ subjects. While the subject age in a study conducted by Chan et $\mathrm{al}^{9}$ was $30.6( \pm 3.9)$ years. There was no significant difference regarding the subject characteristic between the subjects that could be analyzed and the drop-out subject. The present study indicated that most subjects had low BMI in pregnancy. There were only $11(10.6 \%)$ subjects with high BMI and only $4(3.8 \%)$ subjects with obesity.

There was one subject who experienced avulsion on the 6-weeks examination but demonstrated normal result at the 3-months examination. It may occur since the pelvic floor innervations had been restored. Furthermore, there were 4 subjects who had no avulsion at the 6-week examination but developed avulsion at the 3-months examination. Such case probably occurs due to persistent damage of pelvic floor nerves. Our findings are consistent with the results reported by Snooks et $\mathrm{al}^{10}$ as well as by Dietz and Lanzarone ${ }^{11}$ that one third of women who had vaginal delivery would developed avulsion of the fascia layer that supported the pelvic floor muscles within 3 months after the delivery.

The bivariate analysis in this study demonstrated a significant correlation between perineum rupture and the occurrence of levator ani injury with OR of 235.20 (95\% CI: 25.54 - 2166.28). Episiotomy also had effect on levator ani injury with OR of 14.93 (95\% CI: 3.15 - 70.73). Moreover, obesity also had a clinically significant correlation to levator ani injury with OR of 2.58 (95\% CI: 0.70 - 9.53). Other investigators have also reported similar results. Dietz ${ }^{4}$ suggests that episiotomy is biomechanical risk factors in the development of levator ani injury and it is not a protective factor. Moalli et $\mathrm{al}^{7}$ demonstrates that episiotomy and vaginal laceration/ perineum rupture are the risk factors of levator ani injury at the first delivery.

Carroli and Belizan ${ }^{12}$ in Cochrane Review 2009 indicates that episiotomy on indication has significantly involved less trauma to pelvic floor compared to routine episiotomy. Dietz et $\mathrm{al}^{13}$ found that women with lesser BMI had greater risk for levator ani injury. Considering that most Indonesian people have low socio-economic and education level, which may result in low BMI, it could be assumed that Indonesian people are likely to carry high risk for levator ani injury.
In our study, we found that fetal birth weight of $\geq 3325$ $\mathrm{g}$ and duration of second stage labor of $\geq 65$ minutes appeared to have significant correlation with levator injury or avulsion at the third month. Kearney et a ${ }^{14}$ showed that the duration of second stage labor of $\geq 78$ minutes was the risk factor for levator ani injury. Lavy et $\mathrm{al}^{15}$ indicated that there was a positive correlation between high fetal birth weight and levator ani injury after delivery. However, there has been no data about the exact fetal birth weight that may cause levator ani injury. Most experts suggest that fetal birth weight of $\geq 4.5 \mathrm{~kg}$ may cause levator ani injury, while our study showed that the fetal birth weight of $\geq 3325 \mathrm{~g}$ may cause the injury.

In the multivariate analysis, all variables of bivariate analysis were included in the multivariate analysis since all had $\mathrm{p}<0.25$, i.e the BMI during pregnancy, mode of delivery, perineum rupture, episiotomy, duration of second stage labor and fetal birth weight. After several steps, we found a correlation between perineum rupture and episiotomy.

In model 1, after performing several multivariate analysis on levator ani injury in 3 months period, we found that episiotomy and duration of second stage labor longer than 65 minutes and fetal birth weight over $3325 \mathrm{~g}$ could be utilized for the scoring system. After obtaining the regression equation, the subject probability was subsequently calculated by certain score. Following the calculation of subject probability with certain score that could determine the prognosis of levator ani injury, a scoring card was developed, which could be utilized for daily practice. Model 1 could be applied at all health care level since almost every health personnel are able to evaluate second stage labor and episiotomy; while model 2 could only be applied if the medical personnel are able to evaluate perineum rupture. Therefore, trainings about assessment of perineum rupture after delivery for medical personnel are essentially needed. The study limitation includes the lesser sample of the expected. However, it did not affect the final result of our study considering that the odds ratio for almost all variables were $>3$.

An index measurement system model has been developed to represent the role of demographic risk factor (body mass index) and obstetric risk factors (maternal age at delivery, mode of assisted vaginal delivery such as vacuum extraction, duration of second stage, fetal birth, episiotomy and perineum rupture) and the association with levator ani injury at vaginal delivery. However, application of the scoring system in daily practice still requires some case examples so that we could validate the scoring system with the true fact. Further studies with larger sample size are extremely needed before we could determine any policy. 
Modified and applied policy to decrease the incidence of levator ani injury should be determined as policy of preventive strategies, which include the policy about pelvic floor exercise, preventing perineum damage, providing training on grade III perineum tear for general physicians and midwives, establishing guidelines on performing appropriate episiotomy according to the indication or even policy on the elective Caesarian delivery, which is still controversial. Current data and further studies should be considered in those policies. Further studies that support the preventive strategies policies are suggested to be performed on all sectors involving government institutions such as Department of Health, Department of National Education in collaboration with the Collegiums of Obstetrics and Gynecology and Indonesian Midwives Association.

\section{REFERENCES}

1. MacDorman M, Menacker F, Declercq E. Cesarean birth in the United States: epidemiology, trends, and outcomes. Clin Perinatol. 2008;35:293-307.

2. American College of Obstetricians and Gynecologists. ACOG Committee Opinion Number 394, December 2007. Cesarean delivery on maternal request. Obstet Gynecol. 2007;110:1501-4.

3. Dietz HP. Levator trauma in labor: a challenge for obstetricians, surgeons and sonologists. Ultrasound Obstet Gynecol. 2007;29:368-71.
4. Dietz HP. Quantification of major morphological abnormalities of the levator ani. Ultrasound Obstet Gynecol. 2007;29:329-34.

5. Lukacz ES, Lawrence JM, Contreras R, Nager CW, Luber KM. Parity, mode of delivery, and pelvic floor disorders. Obstet Gynecol. 2006;107:1253-60.

6. Sze EHM, Sherrad GB, Dolezal JM. Pregnancy, labor, delivery and pelvic organ prolapse. Obstet Gynecol. 2002;100:981-6.

7. Moalli PA, Ivy SJ, Meyn LA, Zyczynski HM. Risk factors associated with pelvic floor disorders in women undergoing surgical repair. Obstet Gynecol. 2003;101:869-74.

8. Arisman MB. Gizi dalam daur kehidupan: buku ajar ilmu gizi. Jakarta: EGC; 2004. Indonesian.

9. Chan SSC, Cehun RY, Yiu AK, Lee LL, Pang AW, Choy $\mathrm{K}$, et al. Prevalence of levator ani muscle injury in Chinese primiparous women after first delivery. Ultrasound Obstet Gynecol. In press Jan 2012.

10. Snooks SJ, Swash M. The innervation of the muscles of continence. Ann R Coll Surg Engl. 1986;68:45-9.

11. Dietz HP, Lanzarone V. Levator trauma after vaginal delivery. Obstet Gynecol. 2005;106(4):707-12.

12. Carroli G, Belizan J. Episiotomy for vaginal birth. Cochrane Db Syst Rev. 2000;(2):CD000081.

13. Dietz HP, Shek C, Clarke B. Biometry of the pubovisceral muscle and levator hiatus by $3 \mathrm{D}$ pelvic floor ultrasound. Ultrasound Obstet Gynecol. 2005;25:580-5.

14. Kearney R, Miller JM, Ashton-Miller JA, DeLancey JO. Obstetric factors associated with levator ani muscle injury after vaginal birth. Obstet Gynecol. 2006;107:144-9.

15. Lavy Y, Sand PK, Kaniel CI, Celnikier DH. Can pelvic floor injury secondary to delivery be prevented? Int Urogynecol J. In press Aug 2011. 